\title{
Does rheumatoid factor protect lupus patients from the development of nephritis?
}

\author{
L TURNER-STOKES, ${ }^{1}$ M JONES, ${ }^{1}$ I ADDISON ${ }^{2}$ M MANSELL ${ }^{3}$ AND \\ D A ISENBERG ${ }^{1}$
}

From the ${ }^{\prime}$ Bloomsbury Rheumatology Unit, the ${ }^{2}$ Departments of Rheumatology Research and Haematology, University College and the Middlesex Hospital School of Medicine, London, and the ${ }^{3}$ Institute of Nephrology, St Philip's Hospital, London

SUMMARY It has been suggested again recently that the presence of rheumatoid factor (RF) in the serum of patients with systemic lupus erythematosus (SLE) protects them from the 9 development of nephritis. In this study the RF is measured by standard latex test and by radioimmunoassay to detect $\operatorname{IgM}, \operatorname{IgA}$, and IgG isotypes, in patients with SLE with (26 patients) and without (25 patients) renal involvement, and in a control group of 21 patients with idiopathic renal disease. In addition, patients with SLE and nephritis were tested during active and inactive phases of their disease. No significant protective effect was observed from the presence of RF.

Several studies have suggested that rheumatoid factor (RF) protects against the development of renal disease in patients with systemic lupus erythematosus (SLE) ${ }^{1-3}$ This is not universally accepted, however. ${ }^{4-6}$ In the main, previous studies have used only the classical Rose-Waaler or latex tests. These tests detect IgM rheumatoid factor, but not IgG or $\operatorname{IgA}$, and it would seem important to assess the role of all three isotypes. We have therefore, investigated the possible protective effect using both a standard latex test and the more sophisticated technique of radioimmunoassay (RIA), which identifies $\operatorname{IgG}, \operatorname{IgA}$, and $\operatorname{IgM}$ isotypes of rheumatoid factor. Previous authors have analysed their lupus patients in simple groups, for example 'renal' versus 'non-renal', but this does not allow for the important factor of disease activity at the time the patients were studied. In this study we assessed rheumatoid factor in the following patient groups: (a) patients with SLE and renal involvement, tested during active and inactive phases of renal disease $(n=26) ;(b)$ patients with SLE and no renal involvement $(\mathrm{n}=25)$; and (c) patients with idiopathic nephritis, and no evidence of autoimmune rheumatic disease $(n=21)$.

Accepted for publication 12 March 1988

Correspondence to Dr L Turner-Stokes, Department of Rheumatology, 3rd Floor, Arthur Stanley House, Tottenham Street, London W1P 9PG.

\section{Patients, materials and methods}

PATIENTS

Each of the patients with SLE had four or more of the 1982 revised American Rheumatism Association criteria for the classification of SLE. ${ }^{7}$ Twenty six patients with SLE were considered to have renal involvement because three or more of the following had been present at some stage of their illness: diastolic hypertension (fourth phase sound $>90 \mathrm{mmHg}$ ), oedema requiring diuretic treatment not due to any other obvious cause, proteinuria $>0.5 \mathrm{~g} / 24 \mathrm{~h}$, creatinine clearance $<60 \mathrm{ml} / \mathrm{min}$, or $§$ raised plasma creatinine concentration $>124 \mu \mathrm{mol} / \mathrm{l}$.

In 22 of these patients the serum was studied during an active phase of their disease. Renal disease was considered to be active in the presence of a rising diastolic blood pressure, rising plasma or urine creatinine concentrations during a two month period, casts or red blood cells, or both, on urine microscopy, or a renal biopsy showing active inflammation. Serum samples were taken from 16 patients at follow up when they had no evidence of active disease. In addition, four serum samples were $\stackrel{9}{?}$ studied during inactive disease only. Patients with $\square$ SLE and no renal involvement were selected on the basis of their having been followed up for several years without any evidence of the features listed above. The 21 patients with idiopathic renal disease had focal and diffuse glomerulonephritis (GN) (four patients), proliferative GN (six), membranous 
GN (two), mesangial proliferative GN (two), focal GN (one), or IgA nephropathy (six).

\section{MATERIALS AND METHODS}

Rheumatoid factor was assayed by slide latex test in addition to RIA, which was carried out as follows. ${ }^{8}$ Ninety-six-well flexible plates were coated with $100 \mu \mathrm{l}$ of $10 \mu \mathrm{g} / \mathrm{ml}$ human $\mathrm{Fc}$ in phosphate buffered saline (PBS) and incubated for one hour at $37^{\circ} \mathrm{C}$. After washing, the plates were blocked with $0.4 \%$ bovine serum albumin (BSA) for two hours at $37^{\circ} \mathrm{C}$ and washed again in cold PBS. Serum samples were diluted $1 / 100$ in $\mathrm{PBS} / 0.5 \%$ Tween $/ 0.4 \%$ BSA and incubated in $100 \mu \mathrm{l}$ aliquots for a further hour at $37^{\circ} \mathrm{C}$ before washing in cold PBS. The different isotypes of rheumatoid factor were detected by incubating rabbit antihuman IgM (Dako), IgA (Dako), or Fd of human IgG $(5 \mu \mathrm{g} / \mathrm{ml}$ in PBS/ $/ 5 \%$ Tween $/ 0.4 \%$ BSA) for one hour at $37^{\circ} \mathrm{C}$. Bound immunoglobulin was labelled with $5 \mu \mathrm{g} / \mathrm{ml}{ }^{125}$ I goat antirabbit IgG in PBS/0.5\% Tween for one hour. After washing, the plates were counted in a Packard crystal multidetection system. Results were expressed as nanograms of ${ }^{125} \mathrm{I}$ goat antirabbit IgG bound. Upper limits of normal ranges were set at the mean $+2 \mathrm{SD}$ of a normal healthy population $(n=70)$; in this case IgM RF $27 \mathrm{ng}$, IgG RF $35 \mathrm{ng}$, and IgA RF $75 \mathrm{ng}$. The anti-IgM and anti-IgA antiserum (Dako) were both absorbed on a human IgG column and shown to be specific using purified $\operatorname{IgM}, \operatorname{IgA}$, and IgG on the plate. Anti-Fd of IgG was specific for the Fab region of the heavy chain of IgG. Dithiothreitol treatment of serum abolished all IgM RF activity without any effect on the IgA or IgG RF assay. Similarly, no difference was found in the concentrations of RF when pepsin treated antisera were compared with the whole antiserum.

\section{S T A T IS T I CS}

Results were analysed by the $\chi^{2}$ statistical test.

\section{Results}

Table 1 shows the number of patients in each group with positive rheumatoid factor (RF), measured by slide latex test and RIA. Although $7 / 25(28 \%)$ of the patients with SLE without renal lupus were RF positive by latex test as opposed to $2 / 26(8 \%)$ with renal disease, this was not statistically significant. Furthermore, by RIA more patients with SLE and renal disease had RF $(6 / 26(23 \%))$ than those without $(4 / 25(16 \%))$, though the concentrations found were low. In the SLE subgroup with renal disease no differences were found by latex or RIA (IgM, IgG, or IgA) between the active and inactive disease groups. IgG and $\operatorname{IgA}$ were very infrequently
Table 1 Number of patients in each group measured by slide latex test and radioimmunoassay

\begin{tabular}{|c|c|c|c|c|}
\hline $\begin{array}{l}\text { Patient group } \\
\text { (n) }\end{array}$ & $\begin{array}{l}\text { Latex } \\
(>1 / 40)\end{array}$ & $\begin{array}{l}\lg M R F \\
(>27 n g)\end{array}$ & $\begin{array}{l}\lg G R F \\
(>35 n g)\end{array}$ & $\begin{array}{l}\lg A R F \\
(>75 n g)\end{array}$ \\
\hline \multicolumn{4}{|l|}{ SLE with no } & \\
\hline $\begin{array}{l}\text { (25) } \\
\text { SLE with }\end{array}$ & 7 & 4 & - & - \\
\hline $\begin{array}{l}\text { renal disease } \\
\text { (26) }\end{array}$ & 2 & 6 & - & 2 \\
\hline Active (22) & 1 & 3 & - & 1 \\
\hline Inactive $(20)$ & 1 & 3 & - & 1 \\
\hline $\begin{array}{l}\text { Idiopathic } \\
\text { renal disease } \\
\text { (21) }\end{array}$ & - & 2 & - & 1 \\
\hline
\end{tabular}

detected and only $2 / 21(10 \%)$ of the patients with idiopathic renal disease had IgM RF (by RIA).

\section{Discussion}

A protective role for rheumatoid factor in the pathogenesis of lupus nephritis was first suggested by Davis and Bollet. ${ }^{1}$ Demonstration of the reactivity of rheumatoid factor with soluble antigen-antibody complexes to form more heavily sedimenting immune precipitates $^{9}$ has led to speculation that its role may involve formation of less soluble complexes, easily phagocytosed and thus less likely to deposit in the renal glomeruli. Since then there have been a number of conflicting reports concerning this protective role (see Table 2).

There are a number of possible reasons for the disparity between reports. Firstly, it could reflect differences in assay methods, especially as the concentrations of RF in these patients with SLE are low. Most authors employed aggregation tests using either latex particles or red blood cells. Varying results were obtained with either method, and it seems unlikely, therefore, that this accounts for the observed differences, especially as Hill et al demonstrated a protective role in their series using both assays.

A recent report from Helin et al once again found a protective effect, and suggested that differences in patient material could account for the discrepancies, such as the proportion of rheumatoid factor positive patients ( $21 \%$ in their series). ${ }^{3}$ A survey of our own patients with SLE showed a similar proportion$26 / 100(26 \%)$-with a positive rheumatoid factor $(>1 / 40$ by slide latex test). Variable activity of renal disease could also account for the observed differences, however. 
Table 2 Reports on the protective role of rheumatoid factor in the development of lupus nephritis

\begin{tabular}{|c|c|c|c|c|c|c|c|}
\hline Author & SLE defined & $\begin{array}{l}\text { No with } \\
\text { SLE }\end{array}$ & $\begin{array}{l}\text { Renal disease } \\
\text { defined }\end{array}$ & $\begin{array}{l}\text { No with } \\
\text { renal } \\
\text { disease }\end{array}$ & $\begin{array}{l}\text { Active } \\
\text { inactive } \\
\text { phase } \\
\text { studied }\end{array}$ & Assay method & $\begin{array}{l}\text { Protective } \\
\text { effect } \\
\text { (p value) }\end{array}$ \\
\hline Davis and Bollet ${ }^{\prime}$ & Not specified & 35 & Clinical & 23 & No & Not specified & $<() \cdot(x) 1$ \\
\hline Kantor et al ${ }^{+}$ & Clinical & 51 & Not specified & 24 & No & Latex & NS \\
\hline Baldwin et $a^{5}$ & $\begin{array}{l}\text { Clinical }+ \text { ANF } \\
\text { or L.E cells }\end{array}$ & 82 & Biopsy & 27 & No & Latex $>1 / 80$ & NS \\
\hline Hill et $a l^{2}$ & $\begin{array}{l}1971 \text { ARA }^{*} \\
\text { criteria }\end{array}$ & 59 & Biopsy & 59 & No & $\begin{array}{l}\text { Latex }>1 / 80 \\
\text { Rose-Waaler }>1 / 32\end{array}$ & $\begin{array}{l}=0 \cdot(05-0) \cdot 1 \\
<(0) \cdot 05\end{array}$ \\
\hline Helin et $a l^{3}$ & $\begin{array}{l}1982 \text { ARA }^{-} \\
\text {criteria }^{7}\end{array}$ & 52 & $\begin{array}{l}\text { Clinical } \\
\pm \text { biopsy } \\
\text { (in 29) }\end{array}$ & 35 & No & Rose-Waaler $>1 / 64$ & $<0 \cdot()(0) 5$ \\
\hline Pinillos et $a l^{\circ}$ & $\begin{array}{c}1982 \text { ARA } \\
\text { criteria }\end{array}$ & 78 & $\begin{array}{l}\text { Clinical } \\
\pm \text { biopsy } \\
\text { (in 38) }\end{array}$ & 40 & No & Rose-Waaler $>1 / 64$ & NS \\
\hline Tarkowski and Westberg ${ }^{\prime \prime}$ & $\begin{array}{c}1982 \text { ARA } \\
\text { criteria }\end{array}$ & 51 & Clinical & 25 & Yes & $\begin{aligned} \mathrm{EIA}^{*} & \operatorname{lgG} \\
& \operatorname{IgA} \\
& \operatorname{IgM}\end{aligned}$ & $\begin{array}{l}<0 \cdot(001 \\
<0 \cdot 0.5 \\
<0 \cdot 0.5\end{array}$ \\
\hline Present study & $\begin{array}{l}1982 \text { ARA } \\
\text { critcria }\end{array}$ & 51 & $\begin{array}{l}\text { Clinical } \\
\pm \text { biopsy } \\
\text { (in 19) }\end{array}$ & 26 & Yes & $\begin{aligned} \text { Latex } & >1 / 40 \\
\text { RIA* } & \operatorname{IgG} \\
& \operatorname{IgA} \\
& \operatorname{IgM}\end{aligned}$ & $\begin{array}{l}\text { NS } \\
\text { NS } \\
\text { NS } \\
\text { NS }\end{array}$ \\
\hline
\end{tabular}

*ANF=antinuclear factor: ARA = American Rheumatism Association: EIA=enzyme linked immunoassay; RIA=radioimmunoassay.

To address these possibilities we studied patients both in active and inactive phases of their disease, and in addition to the standard latex test we used an RIA technique, which distinguishes the three isotypes of rheumatoid factor. Our results show that although a trend towards a protective role for rheumatoid factor against the development of renal disease was seen by the latex test, this was not statistically significant. Furthermore, analysis by RIA showed no protection at all. In addition, activity of the lupus nephritis made no difference.

Very recently Tarkowski and Westberg measured rheumatoid factor isotypes by enzyme linked immunoassay and reported a protective role for all three, especially for IgG. ${ }^{10}$ They suggested that by competing with complement for binding with immune complexes, and thus minimising their injurious properties, IgG RF could be more protective than IgM. Against this however, was the correlation of active disease with the presence of IgM rheumatoid factor isotypes in their study.

The protective role for rheumatoid factor against the development of nephropathy in SLE remains contentious. The failure of two recent studies to show a correlation with disease activity suggests, however, that its pathogenetic role can at best be small.

\section{References}

1 Davis J S. Bollet A J. Complement levels, rheumatoid factor and renal disease in systemic lupus erythematosus. Arthritis Rheum 1966: 9: 499-5(1).

2 Hill G S. Hinglais N. Tron F. Bach J-F. Morphologic correlations with immunologic and clinical data at the time of biopsy. Am J Med 1978: 64: 61-79.

3 Helin H, Korpela M, Mustonen J, Pasternack A. Rheumatoid factor in rheumatoid arthritis associated renal discase and in lupus nephritis. Ann Rheum Dis 1986; 45: 508-11.

4 Kantor G L. Bickel Y B. Barnett E V. Coexistence of systemic lupus erythematosus and rheumatoid arthritis. Am J Med 1969 47: 433-44.

5 Baldwin D S, Lowenstein J. Rothfield N F. Gallo G. McClusky I R T. The elinical course of the proliferative and membranous forms of lupus nephritis. Ann Intern Med 1970; 73: 929-42.

6 Pinillos R M. Solc J M N. Roura X J. Ferraz V P. Palacin A V. N Sampere I M. Rheumatoid factor in patients with systemic lupus erythematosus. Ann Rheum Dis 1987; 46: 877-8.

7 Tan E M. Cohen A S. Fries J F. et al. The 1982 revised criteria N for the classification of systemic lupus erythematosus. Arthritis 0 Rheum 1982; 25: 1271-7.

8 Jones M G. Antiglobulins in rheumatoid arthritis. London University, 1982. (PhD thesis.)

9 Lightwood R W, Drusin R E, Christian C L. The interaction of $\stackrel{\mathscr{S}}{+}$ soluble immune complexes with rheumatoid factors. Ann NY Acad Sci 1969; 168: 105-10.

10 Tarkowski A, Westberg G. Rheumatoid factor isotypes and $\stackrel{\vec{D}}{\vec{P}}$ renal disease in systemic lupus erythematosus. Scand $J \cong$ Rheumatol 1987; 16: 309-12.

11 Cohen A S, Reynolds W E, Franklin E C, et al Preliminary criteria for the classification of systemic lupus erythematosus Bull Rheum Dis 1971; 21: 643-8. 